\title{
Effect of Vanadium on Splenocyte Apoptosis in Broilers
}

\section{Cui Wei, Cui Hengmin*, Peng Xi, Fang Jing, Liu Xiaodong and Wu Bangyuan}

Key Laboratory of Animal Diseases and Environmental Hazards of Sichuan Province, College of Veterinary Medicine, Sichuan Agricultural University, Ya'an 625014, China

\begin{abstract}
A total of 420 one-day-old healthy broilers were divided into six groups. There were 70 broilers in each group. The broilers were fed on a corn-soybean basal diet as a control diet (vanadium $0.073 \mathrm{mg} / \mathrm{kg}$ ) or the same diet amended to contain $5 \mathrm{mg} / \mathrm{kg}, 15 \mathrm{mg} / \mathrm{kg}, 30 \mathrm{mg} / \mathrm{kg}, 45 \mathrm{mg} / \mathrm{kg}$ and $60 \mathrm{mg} / \mathrm{kg}$ vanadium supplied as ammonium metavanadate for 42 days. When compared with those of the control group, the mitochondrial injury of splenocytes and more apoptotic splenocytes with condensed chromatin with C-shaped, horseshoe-like, petal-shaped or crescent were ultrastructurally observed in the spleen in the $30 \mathrm{mg} / \mathrm{kg}, 45 \mathrm{mg} / \mathrm{kg}$ and $60 \mathrm{mg} / \mathrm{kg}$ groups. As measured by flow cytometry (FCM), the number of apoptotic splenocytes was significantly increased in the $15 \mathrm{mg} / \mathrm{kg}, 30 \mathrm{mg} / \mathrm{kg}, 45 \mathrm{mg} / \mathrm{kg}$ and $60 \mathrm{mg} /$ $\mathrm{kg}$ groups. Immunohistochemical tests showed that number of positive splenocytes containing Bax and caspase-3 protein was increased, and number of positive splenocytes containing Bcl-2 protein was decreased in the $15 \mathrm{mg} / \mathrm{kg}$, $30 \mathrm{mg} / \mathrm{kg}, 45 \mathrm{mg} / \mathrm{kg}$ and $60 \mathrm{mg} / \mathrm{kg}$ groups. It was concluded that dietary vanadium in excess of $15 \mathrm{mg} / \mathrm{kg}$ could result in splenocyte apoptosis in broilers. Splenocyte apoptosis was closely related to mitochondrial injury and changed expression of apoptogenic proteins induced by vanadium.
\end{abstract}

Keywords: Dietary vanadium; Apoptosis; Flow cytometry (FCM); Spleen; Broilers

\section{Introduction}

It has been proven that vanadium is an activator of adenyl cyclase, a potent anti-carcinogenic agent and potent inhibitors of several phosphohydrolases, such as $\mathrm{Na}^{+} \mathrm{K}^{+}$-ATPase and $\mathrm{Ca}^{2+}$-ATPase [1-5]. Also, as an antidiabetic agent, vanadium plays role of insulin [6-8]. At the same time, several reports have shown that vanadium can cause toxic effects on cells or organs, such as oxidative damage (or stress) in rats [9-12] and broilers [13,14], and immunotoxicity in broilers [1519].

Spleen is the principal peripheral lymphoid organ and plays an important role in protective immune reactions. There are no reports regarding effect of vanadium on splenocyte apoptosis in broilers. In our recent study, dietary vanadium in the range of $30 \mathrm{mg} / \mathrm{kg}-60$ $\mathrm{mg} / \mathrm{kg}$ can cause lymphocyte apoptosis in bursa of Fabricius [20], and splenic lesions, inhibition of the splenic growth [16]. As a part of our study on effect of vanadium on spleen, the same broilers were used in the present study to investigate changes of percentages of the splenocyte apoptosis by the methods of pathology, flow cytometry (FCM) and immunohistochemistry, and to evaluate changes of the splenic function in broilers.

\section{Materials and Methods}

\section{Chickens and diets}

Four hundred and twenty one-day-old healthy broilers were divided into six groups. There were 70 broilers in each group. The broilers were housed in cages with electrically heated units and were provided with water as well as experimental diets ad libitum for 42 days. A corn-soybean basal diet formulated by the National Research Council (NRC, 1994) was the control diet (vanadium $0.073 \mathrm{mg} /$ $\mathrm{kg})$. Ammonium metavanadate $\left(\mathrm{NH}_{4} \mathrm{VO}_{3}\right)$ was mixed into the cornsoybean basal diet to produce $5 \mathrm{mg} / \mathrm{kg}, 15 \mathrm{mg} / \mathrm{kg}, 30 \mathrm{mg} / \mathrm{kg}, 45 \mathrm{mg} / \mathrm{kg}$ and $60 \mathrm{mg} / \mathrm{kg}$ vanadium diets.

All experimental procedures involving animals were approved by Sichuan Agricultural University Animal Care and Use Committee.

\section{Ultrastructural observation}

At the end of the experiment, three chickens in each group were euthanized and immediately necropsied. Spleens were dissected and fixed in $2.5 \%$ glutaraldehyde and postfixed in $2 \%$ veronal acetatebuffered $\mathrm{OsO}_{4}$. After dehydration in graded alcohol, the fixtures were embedded in araldite. The blocks were sectioned in a microtome with a glass knife. The sections, $65-75 \mathrm{~nm}$ thick, were placed in uncoated copper grids. They were then stained with uranyl acetate, poststained with $0.2 \%$ lead citrate, and examined with an electron microscope.

\section{Annexin V apoptosis detection by flow cytometry}

Five chickens in each group were humanely killed when the birds were 14,28 , and 42 days old, and the spleens were immediately taken and ground to form a cell suspension. This suspension was filtered through a 300-mesh nylon screen. The cells were washed twice with cold PBS (phosphate buffer solution, $\mathrm{pH}$ 7.2-7.4) and then suspended in $1 \mathrm{x}$ binding buffer (Cat. No. 51-66121E) at a concentration of $1 \times$ $10^{6}$ cells $/ \mathrm{mL}$. One-hundred- $\mu \mathrm{L}$ portions of the cell suspension were transferred $5-\mathrm{mL}$ culture tubes, and $5 \mu \mathrm{L}$ of Annexin V-FITC (Cat. No. 51-65874X) and $5 \mu \mathrm{L}$ of PI (Cat. No. 51-66211E) were added. The mixture was gently vortexed and incubated for 15 minutes at $25^{\circ} \mathrm{C}$ in the dark. $400 \mu \mathrm{L}$ of $1 \mathrm{x}$ binding buffer was added to each tube. Analysis by flow cytometry (BD FACSCalibur) was conducted within 1 hour.

\section{$\mathrm{Bax} / \mathrm{Bcl}-2$, and caspase-3 protein detection}

At 14, 28 and 42 days of age, five broilers in each group were humanely killed. Spleens were taken for $\mathrm{Bax} / \mathrm{Bcl}-2$ and caspase-3 detection by the immunohistochemical methods (SABC) and stained with $\mathrm{DAB}$ as described by Wang et al [21]. Anti-Bax (BA0315), anti-Bcl-2 (BA0412) and anti-Caspase-3 (BA0588), and DAB were purchased from Wuhan Boster Biological Technology Co., Ltd., China.

*Corresponding author: Cui Hengmin Ph.D, Professor, College of Veterinary Medicine, Sichuan Agricultural University, Yaan, Sichuan, China 625014, Tel: +86-13608264628; Fax: +86-0835-2882340; E-mail: cuihengmin2008@sina.com, cui580420@sicau.edu.cn

Received March 14, 2012; Accepted March 30, 2012; Published April 02, 2012 Citation: Wei C, Hengmin C, Xi P, Jing F, Xiaodong L, et al. (2012) Effect of Vanadium on Splenocyte Apoptosis in Broilers. Med chem 2: 057-060. doi:10.4172/2161-0444.1000115

Copyright: (C) 2012 Wei C, et al. This is an open-access article distributed under the terms of the Creative Commons Attribution License, which permits unrestricted use, distribution, and reproduction in any medium, provided the original author and source are credited. 


\section{Image analysis}

Images from five slices per spleen were taken $200 \mu \mathrm{m}$ apart. Five visions per slice were randomly chosen for assessment of positive cells using image analysis software (JID801D). The average grayscale of the positive cells was automatically calculated. Immunoreactive intensity were expressed by average grayscale. Values $<160$ was considered high, 160-170 medium and 170-180 low.

\section{Statistical analysis}

The significance of difference among the six groups was analyzed by variance-analysis, and results were presented as means \pm standard deviation $(X \pm S)$. The analysis was done using SPSS 12.0 for Windows.

\section{Results}

\section{Clinical observation}

Results showed as in the reference [22].

\section{Ultrastructural changes}

No obvious abnormal ultrastructural changes were observed in the $5 \mathrm{mg} / \mathrm{kg}$ and $15 \mathrm{mg} / \mathrm{kg}$ groups compared to the control group (Figure 1A). The mitochondria of splenocytes were enlarged and vacuolated with degenerating cristae (Figure 1B-C) in the $30 \mathrm{mg} / \mathrm{kg}, 45 \mathrm{mg} / \mathrm{kg}$, and $60 \mathrm{mg} / \mathrm{kg}$ groups. Also, apoptotic splenocytes were found to be increased in the $30 \mathrm{mg} / \mathrm{kg}, 45 \mathrm{mg} / \mathrm{kg}$, and $60 \mathrm{mg} / \mathrm{kg}$ groups. These apoptotic cells are characterized as the typical condensed chromatin with C-shaped, horseshoe-like, petal-shaped or crescent (Figures1B-D).

\section{Results of Annexin V apoptosis detection by flow cytometry}

The results in Table 1 showed that the percentage of apoptotic cells in the spleen was increased as dietary vanadium level increased. The percentage of apoptotic splenocytes was significantly higher $(P<0.01)$ in the $15 \mathrm{mg} / \mathrm{kg}, 30 \mathrm{mg} / \mathrm{kg}, 45 \mathrm{mg} / \mathrm{kg}$ and $60 \mathrm{mg} / \mathrm{kg}$ groups than that in the control group.

\section{Results of Bax, Bcl-2 and caspase- 3 protein detection}

The population of positive splenocytes containing Bax protein (brown-stain) was increased in the $15 \mathrm{mg} / \mathrm{kg}, 30 \mathrm{mg} / \mathrm{kg}, 45 \mathrm{mg} / \mathrm{kg}$ and $60 \mathrm{mg} / \mathrm{kg}$ groups when compared with that of the control group. Average gray scales of the positive cells were significantly lower $(P<0.01)$ in the $30 \mathrm{mg} / \mathrm{kg}, 45 \mathrm{mg} / \mathrm{kg}$ and $60 \mathrm{mg} / \mathrm{kg}$ groups than those in the control group from 14 to 42 days of age, and significantly lower $(P<0.01)$ in the $15 \mathrm{mg} / \mathrm{kg}$ group than those in the control group from 28 to 42 days of age.

The frequencies of positive splenocytes containing Bcl-2 protein (brown-stain) were decreased in the $15 \mathrm{mg} / \mathrm{kg}, 30 \mathrm{mg} / \mathrm{kg}, 45 \mathrm{mg} / \mathrm{kg}$ and $60 \mathrm{mg} / \mathrm{kg}$ groups in comparison with those of the control group. Meanwhile, average gray scales of positive cells were significantly higher $(P<0.01)$ in the $30 \mathrm{mg} / \mathrm{kg}, 45 \mathrm{mg} / \mathrm{kg}$ and $60 \mathrm{mg} / \mathrm{kg}$ groups than those in the control group during the experiment, and were significantly increased $(P<0.01)$ in $15 \mathrm{mg} / \mathrm{kg}$ group at 28 and 42 days of age.

Changes of the positive cells containing caspase- 3 protein (brownstained) were the same with the positive splenocytes containing Bax protein.

The results were showed in Tables 2-4 and Figures 2-4.

\section{Discussion}

Apoptosis has been characterized as a fundamental cellular activity occurring under a wide range of physiological and pathological conditions [23]. Vanadate-containing compounds exert potent toxicity,

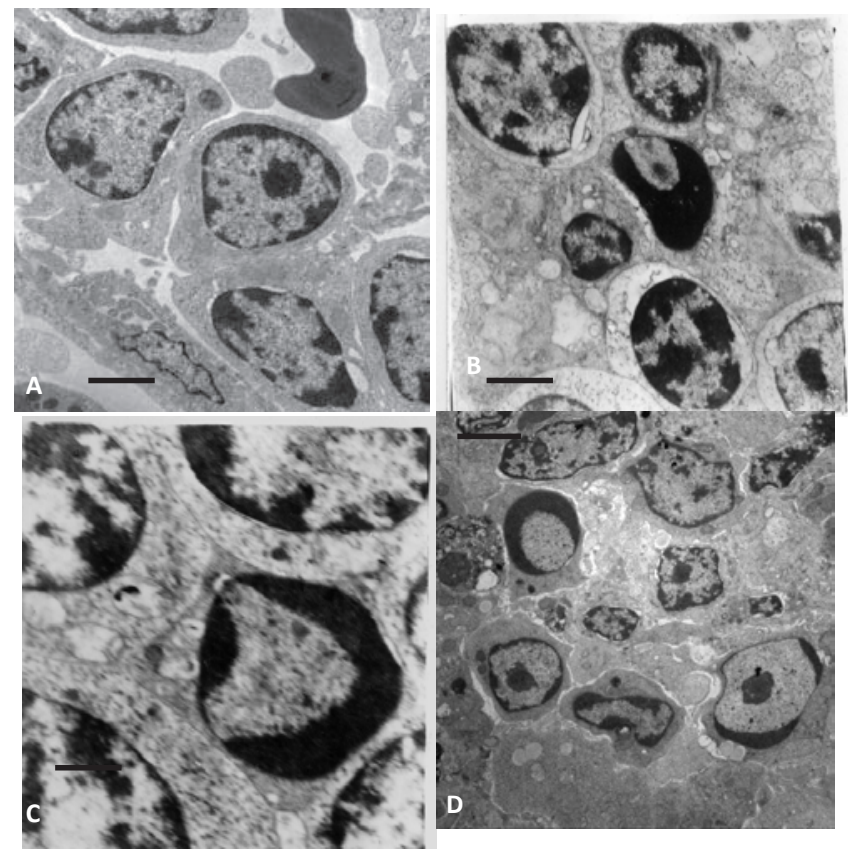

Figure 1: A. The ultrastructure of spleen in the control group. Bar=2 $\mu \mathrm{m}$. B. There is an apoptotic splenocyte in the $30 \mathrm{mg} / \mathrm{kg}$ group. Bar=2 $\mu \mathrm{m}$. C. There is an apoptotic splenocyte in the $45 \mathrm{mg} / \mathrm{kg}$ group. Bar=1.5 $\mu \mathrm{m}$. D. There are four apoptotic splenocytes in the $60 \mathrm{mg} / \mathrm{kg}$ group. Bar=3 $\mu \mathrm{m}$. B and $\mathbf{C}$. Mitochondria of the splenocytes are enlarged and vacuolated with degenerating cristae.

\begin{tabular}{llll}
\hline & 14 days & 28 days & 42 days \\
\hline control & $4.92 \pm 0.46$ & $5.67 \pm 0.57$ & $5.80 \pm 0.70$ \\
$5 \mathrm{mg} / \mathrm{kg}$ group & $5.61 \pm 0.56$ & $6.74 \pm 0.70$ & $7.31 \pm 0.81$ \\
$15 \mathrm{mg} / \mathrm{kg}$ group & $8.63 \pm 0.95^{* *}$ & $9.17 \pm 1.00^{* *}$ & $10.14 \pm 1.10^{* *}$ \\
$30 \mathrm{mg} / \mathrm{kg}$ group & $10.49 \pm 0.84^{* *}$ & $11.86 \pm 1.07^{* *}$ & $12.84 \pm 1.07^{* *}$ \\
$45 \mathrm{mg} / \mathrm{kg}$ group & $12.27 \pm 1.04^{* *}$ & $11.92 \pm 0.81^{* *}$ & $13.26 \pm 1.07^{* *}$ \\
$60 \mathrm{mg} / \mathrm{kg}$ group & $14.82 \pm 1.03^{* *}$ & $14.64 \pm 1.07^{* *}$ & $16.90 \pm 1.04^{* *}$
\end{tabular}

Data are the means \pm standard deviation $(n=5)$

${ }^{*} p<0.05$, compared with the control group

${ }^{* *} p<0.01$, compared with the control group

Table 1: The changes on percentage of apoptotic cells of spleen

\begin{tabular}{llll}
\hline & 14 days & 28 days & 42 days \\
\hline control & $184.22 \pm 11.29$ & $185.50 \pm 12.24$ & $187.52 \pm 11.29$ \\
$5 \mathrm{mg} / \mathrm{kg}$ group & $180.52 \pm 11.25$ & $179.94 \pm 12.03$ & $180.58 \pm 12.48$ \\
$15 \mathrm{mg} / \mathrm{kg}$ group & $177.06 \pm 10.91$ & $166.59 \pm 11.49^{* *}$ & $167.36 \pm 10.90^{* *}$ \\
$30 \mathrm{mg} / \mathrm{kg}$ group & $166.36 \pm 10.69^{* *}$ & $166.27 \pm 10.07^{* *}$ & $166.26 \pm 10.65^{\star *}$ \\
$45 \mathrm{mg} / \mathrm{kg}$ group & $164.59 \pm 10.32^{* *}$ & $157.86 \pm 10.12^{* *}$ & $157.99 \pm 10.78^{* *}$ \\
$60 \mathrm{mg} / \mathrm{kg}$ group & $153.94 \pm 9.39^{* *}$ & $154.89 \pm 10.61^{* *}$ & $144.59 \pm 10.87^{* *}$
\end{tabular}

Data are the means \pm standard deviation $(n=5 \times 5)$

${ }^{*} \mathrm{p}<0.05$, compared with the control group

${ }^{* *} p<0.01$, compared with the control group

Table 2: The average gray scales of Bax positive cells in the spleen.

causing DNA damage, which results in DNA damage that is one of major incentives initiating apoptosis [24]. Chromatin condensation in the apoptotic splenocytes was ultrastructurally observed in the present study. Also, the results determined by FCM showed that the percentages of apoptotic splenocytes were significantly increased in the $15 \mathrm{mg} / \mathrm{kg}$, $30 \mathrm{mg} / \mathrm{kg}, 45 \mathrm{mg} / \mathrm{kg}$ and $60 \mathrm{mg} / \mathrm{kg}$ groups. It was further testified from the results in the present study that dietary high vanadium can cause cellular apoptosis in the lymphoid organs in broilers. 
Citation: Wei C, Hengmin C, Xi P, Jing F, Xiaodong L, et al. (2012) Effect of Vanadium on Splenocyte Apoptosis in Broilers. Med chem 2: 057-060. doi:10.4172/2161-0444.1000115

\begin{tabular}{llll}
\hline & 14 days & 28 days & 42 days \\
\hline control & $148.59 \pm 10.55$ & $153.94 \pm 13.05$ & $150.26 \pm 12.42$ \\
$5 \mathrm{mg} / \mathrm{kg}$ group & $150.27 \pm 10.05$ & $157.69 \pm 13.12$ & $154.10 \pm 13.21$ \\
$15 \mathrm{mg} / \mathrm{kg}$ group & $153.94 \pm 11.03$ & $166.23 \pm 12.03^{*}$ & $166.13 \pm 13.80^{*}$ \\
$30 \mathrm{mg} / \mathrm{kg}$ group & $157.58 \pm 11.25^{*}$ & $166.85 \pm 12.82^{*}$ & $168.89 \pm 12.30^{* *}$ \\
$45 \mathrm{mg} / \mathrm{kg}$ group & $166.13 \pm 13.36^{* *}$ & $177.35 \pm 14.17^{* *}$ & $178.00 \pm 15.54^{* *}$ \\
$60 \mathrm{mg} / \mathrm{kg}$ group & $178.77 \pm 14.13^{* *}$ & $187.25 \pm 13.15^{* *}$ & $186.17 \pm 16.51^{* *}$ \\
\hline
\end{tabular}

Data are the means \pm standard deviation $(n=5 \times 5)$

${ }^{*} p<0.05$, compared with the control group

${ }^{* *} p<0.01$, compared with the control group

Table 3: The average gray scales of Bcl-2 positive cells in the spleen.

\begin{tabular}{llll}
\hline & 14 days & 28 days & 42 days \\
\hline control & $178.68 \pm 8.19$ & $174.27 \pm 12.92$ & $174.96 \pm 13.92$ \\
$5 \mathrm{mg} / \mathrm{kg}$ group & $176.98 \pm 10.35$ & $169.85 \pm 13.06$ & $172.41 \pm 12.29$ \\
$15 \mathrm{mg} / \mathrm{kg}$ group & $172.11 \pm 12.20$ & $162.41 \pm 13.96^{*}$ & $166.40 \pm 8.80$ \\
$30 \mathrm{mg} / \mathrm{kg}$ group & $162.41 \pm 9.70^{* *}$ & $153.98 \pm 9.99^{* *}$ & $156.40 \pm 9.67^{* *}$ \\
$45 \mathrm{mg} / \mathrm{kg}$ group & $156.26 \pm 9.26^{* *}$ & $149.84 \pm 9.26^{* *}$ & $152.11 \pm 9.26^{* *}$ \\
$60 \mathrm{mg} / \mathrm{kg}$ group & $149.42 \pm 10.09^{* *}$ & $144.14 \pm 9.56^{* *}$ & $144.27 \pm 9.68^{* *}$ \\
\hline
\end{tabular}

Data are the means \pm standard deviation $(n=5 \times 5)$

${ }^{*} \mathrm{p}<0.05$, compared with the control group

${ }^{* *} \mathrm{p}<0.01$, compared with the control group

Table 4: The average gray scales of Caspase-3 positive cells in the spleen.

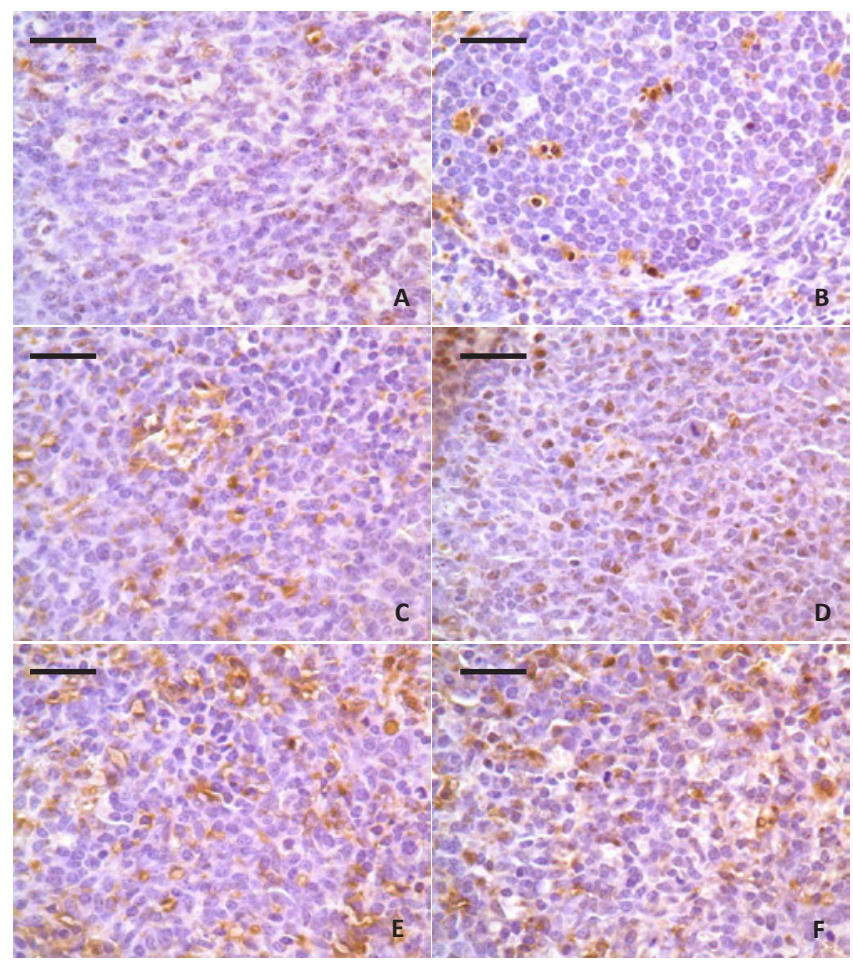

Figure 2: The spleens are stained for Bax protein at 42 days of age. There are several positive splenocytes (brown-stain) in control group (A). The positive splenocytes is slightly increased in $5 \mathrm{mg} / \mathrm{kg}$ group (B) and markedly increased in $15 \mathrm{mg} / \mathrm{kg}, 30 \mathrm{mg} / \mathrm{kg}, 45 \mathrm{mg} / \mathrm{kg}$ and $60 \mathrm{mg} / \mathrm{kg}$ groups (C, D, E, F). SABC. Bar $=20 \mu \mathrm{m}$.

Vanadium-induce apoptosis may be related to mitochondrial injury [25]. Vacuolated mitochondria with degenerating cristae were ultrastructurally observed in the present study. Because Bcl-2 is expressed in the inner mitochondrial membrane [26], mitochondrial injury can cause mitochondrial apoptogenic proteins, such as those of the Bcl-2 family, from mitochondria to the cytoplasm [25] that initiates apoptotic process. Meanwhile, the Bcl-2 protein family regulates the release of apoptosis-activating factors and the ratio of Bcl-2 to Bax determines cell survival or death [27]. In the present study, positive cell population of the $\mathrm{Bcl}-2$ protein expression was decreased while positive cell population of the Bax protein expression was increased in the $15 \mathrm{mg} / \mathrm{kg}, 30 \mathrm{mg} / \mathrm{kg}$, $45 \mathrm{mg} / \mathrm{kg}$ and $60 \mathrm{mg} / \mathrm{kg}$ groups, which is consistent with the results observed in the bursa of Fabricius of our recent report [20]. At present, there are no systematic studies on effect of vanadium on expression of Bcl-2 protein family except our report [20]. The broken balance between expression of Bcl-2 and Bax proteins not only induces apoptotic process, but also activates caspase- 3 protein [28]. Positive cell population of the caspase- 3 protein expression was increased in the $15 \mathrm{mg} / \mathrm{kg}, 30 \mathrm{mg} / \mathrm{kg}, 45 \mathrm{mg} / \mathrm{kg}$, and $60 \mathrm{mg} / \mathrm{kg}$ groups in the present study, the above mentioned changes of apoptogenic protein expression finally resulted in an increase in apoptotic splenocytes.

It has been shown that mitochondrial injury and expression of proapoptotic proteins are related to the production of free radicals. In our another report [20], the results have shown that dietary vanadium in the range of $30 \mathrm{mg} / \mathrm{kg}-60 \mathrm{mg} / \mathrm{kg}$ can decrease activities of SOD and GSH- $\mathrm{P}_{\mathrm{x}}$, and ability to inhibit hydroxyl radical, and increase MDA content, which induces oxidative damage and lipid peroxidation in the spleen of broilers. Decreased activities of antioxidant enzymes, increased lipid peroxidation and accumulated free radicals in the spleen induce mitochondrial injury and alter expression of apoptotic proteins, which finally results in splenocyte apoptosis.

In conclusion, dietary vanadium in excess of $15 \mathrm{mg} / \mathrm{kg}$ can cause splenocyte apoptosis and impact splenic function in broilers. Splenocyte apoptosis is closely related to mitochondrial injury and changed expression of apoptogenic proteins induced by vanadium.

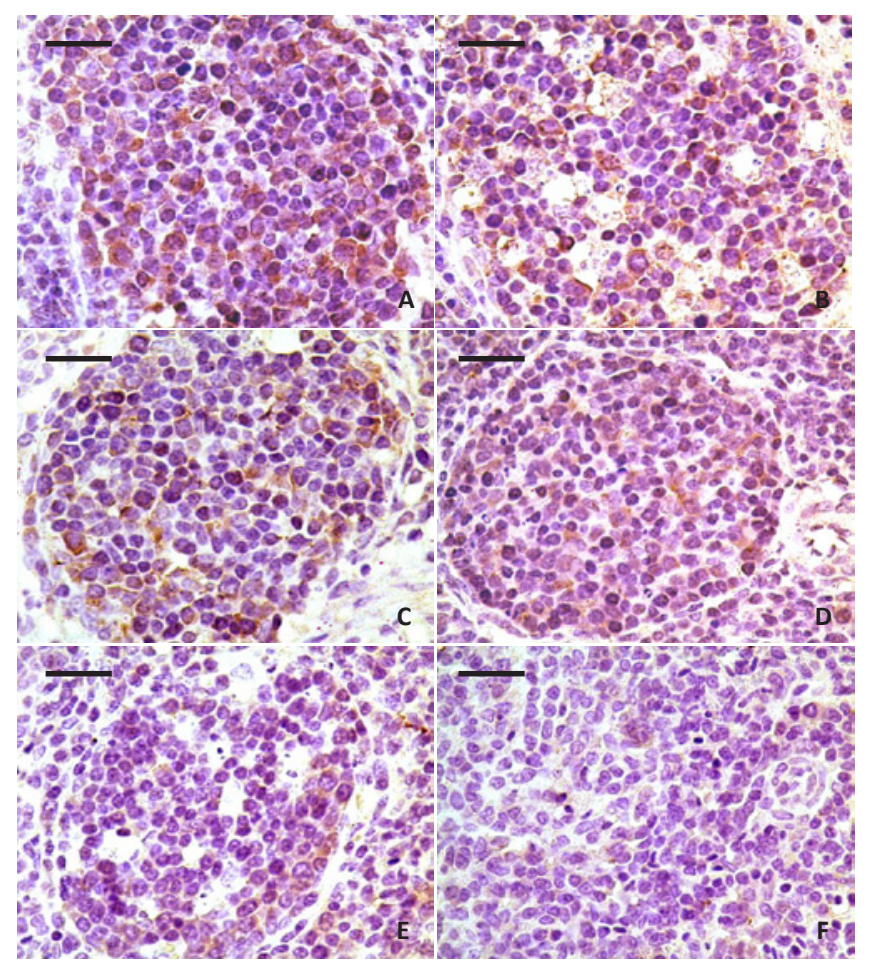

Figure 3: The spleens are stained for $\mathrm{Bcl}-2$ protein at 42 days of age. There are many positive splenocytes (brown-stain) in control group (A). The positive splenocytes are not changed in $5 \mathrm{mg} / \mathrm{kg}$ group (B), and are markedly decreased in $15 \mathrm{mg} / \mathrm{kg}, 30 \mathrm{mg} / \mathrm{kg}, 45 \mathrm{mg} / \mathrm{kg}$ and $60 \mathrm{mg} / \mathrm{kg}$ groups (C, D, E, F). SABC. Bar $=20 \mu \mathrm{m}$. 
Citation: Wei C, Hengmin C, Xi P, Jing F, Xiaodong L, et al. (2012) Effect of Vanadium on Splenocyte Apoptosis in Broilers. Med chem 2: 057-060. doi:10.4172/2161-0444.1000115

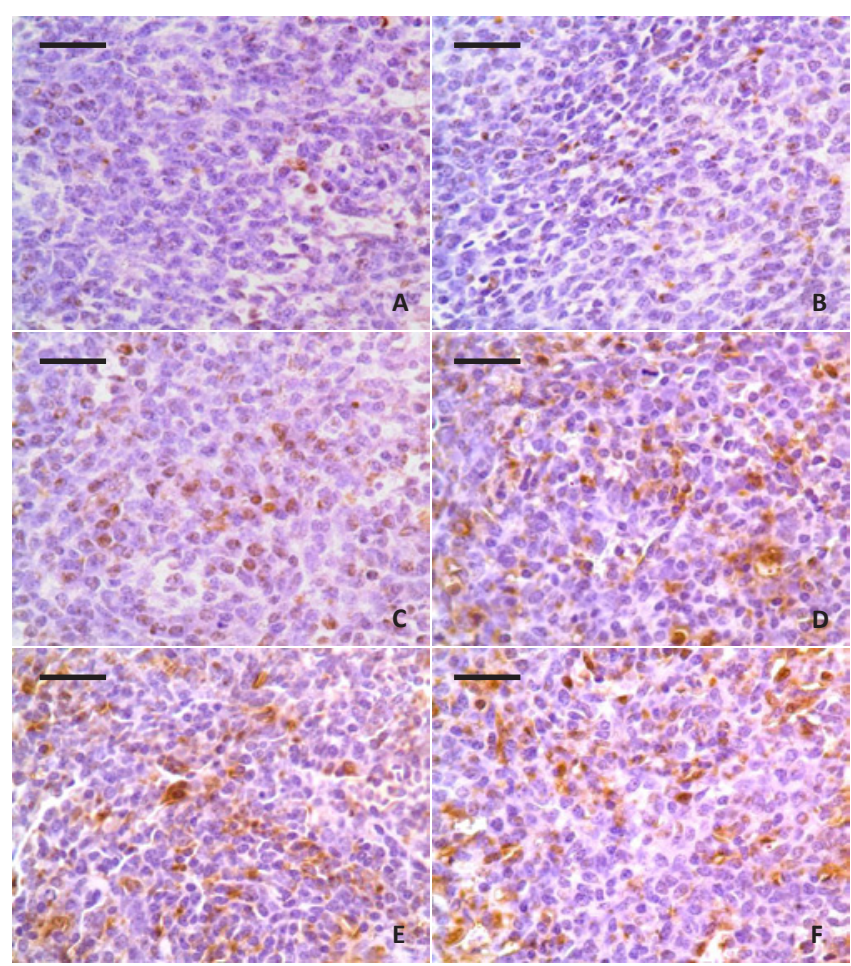

Figure 4: The spleens are stained for Caspase-3 protein at 42 days of age. There are several positive splenocytes (brown-stain) in control group (A). The positive splenocytes are slightly increased in $5 \mathrm{mg} / \mathrm{kg}$ group (B) and markedly increased in $15 \mathrm{mg} / \mathrm{kg}, 30 \mathrm{mg} / \mathrm{kg}, 45 \mathrm{mg} / \mathrm{kg}$ and $60 \mathrm{mg} / \mathrm{kg}$ groups (C, D, E, F). SABC. Bar $=20 \mu \mathrm{m}$.

\section{Acknowledgment}

The study was supported by the program for Changjiang scholars and innovative research team in university (IRT 0848) and the key program of Education Department and Scientific department of Sichuan Province (09ZZ017).

\section{References}

1. Norgaard A, Kjeldsen K, Hansen O, Clausen T (1983) A simple and rapid method for the determination of the number of $3 \mathrm{H}$-ouabain binding sites in biopsies of skeletal muscle. Biochem Biophys Res Commun 111: 319-325.

2. BR Nechay (1984) Mechanisms of action of vanadium. Ann Rev Pharmcol Toxicol 24: 501-524.

3. Schmitz W, Scholz H, Erdmann E, Krawietz W, Werdan K (1982) Effect of Vanadium in the $+5,+4$ and +3 oxidation states on cardiac force of contraction, adenylate cyclase and $\left(\mathrm{Na}^{+}, \mathrm{K}^{+}\right)$-ATPase activity. Biochem Pharmacol 31 : 3853-3860.

4. Bishayee A, Chatterjee M (1995) Time course effects of vanadium supplement on cytosolic reduced glutathione level and glutathione S-transferase activity. Biol Trace Elem Res 48: 275-285.

5. Shrivastava S, Joshi D, Bhadauria M, Shukla S, Mathur R (2011) Cotherapy of Tiron and selenium against vanadium induced toxic effects in lactating rats. Iran J Reprod Med 9: 229-238.

6. Duckworth WC, Solomon SS, Liepnieks J, et a1. (1998) Insulin-like effects of vanadium in isolated rat adipocytes. Endoerinology 122: 2285-2289.

7. Crans DC, Smee JJ, Gaidamauskas E, Yang L (2004) The chemistry and biochemistry of vanadium and the biological activities exerted by vanadium compounds. Chem Rev 104: 849-902.
8. Domingo JL (2002) Vanadium and tungsten derivatives as antidiabetic agents: a review of their toxic effects. Biol Trace Elem Res 88: 97-112.

9. Liochev SI, Fridovich I (1990) Vanadate-stimulated oxidation of NAD(P)H in the presence of biological membranes and other sources of O2-. Arch Biochem Biophys 279: 1-7.

10. Feng BM, Sun SL, Yang CQ (2008) Effects of vanadium on GSH-Px activity in muscle of mice. Progress in Vet Med 29: 42-44.

11. Mukherjee B, Patra B, Mahapatra S, Banerjee P, Tiwari A, et al. (2004) Vanadium-an element of atypical biological significance. Toxicol Lett 150: 135143.

12. Rehder D (2011) Transport, Accumulation, and Physiological Effects of Vanadium. In: Irena Sherameti I, Varma A (eds) Detoxification of Heavy Metals, ( $1^{\text {st }}$ edn), Springer, New York.

13. Deng Y, Cui H, Peng X, Fang J, Wang K, et al. (2012) Dietary vanadium induces oxidative stress in the intestine of broilers. Biol Trace Elem Res 145: 52-58.

14. Liu J, Cui H, Liu X, Peng X, Deng J, et al. (2012) Dietary high vanadium causes oxidative damage-induced renal and hepatic toxicity in broilers. Biol Trace Elem Res 145: 189-200.

15. Cui W, Cui H, Peng X, Fang J, Zuo Z, et al. (2011) Changes of relative weigh and cell cycle, and lesions of bursa of Fabricius induced by dietary excess vanadium in broilers. Biol Trace Elem Res 143: 251-260.

16. Cui W, Cui H, Peng X, Fang J, Zuo Z, et al. (2011) Dietary excess vanadium induces lesions and changes of cell cycle of spleen in broilers. Biol Trace Elem Res 143: 949-956.

17. Cui W, Cui H, Peng X, Fang J, Zuo Z, et al. (2011) Excess dietary vanadium induces the changes of subsets and proliferation of splenic $T$ cells in broilers. Biol Trace Elem Res 143: 932-938.

18. Cui W, Cui HM, Peng X, Zuo Z, liu X, et al. (2011) Effect of vanadium on the subset and proliferation of peripheral blood T-cells and serum IL-2 content in broilers. Biol Trace Elem Res 141: 192-199.

19. Deng Y, Cui H, Peng X, Fang J, Wang K, et al. (2011) Effect of dietary vanadium on cecal tonsil T-cell subsets and IL-2 contents in broilers. Biol Trace Elem Res 144: 647-656.

20. Cui W, Cui H, Peng X, Fang J, Zuo Z, et al. (2012) Dietary vanadium induces lymphocyte apoptosis in the bursa of Fabricius of broilers. Biol Trace Elem Res 146: 59-67.

21. Wang JM, Xiao BL, Zheng JW, Chen HB, Zou SQ, et al. (2007) Effect of targeted magnetic nanoparticles containing 5 -FU on expression of bcl-2, bax and caspase- 3 in nude mice with transplanted human liver cancer. World $J$ Gastroenterol 13: 3171-3175.

22. Cui W, Cui H M, Peng Xi, et al. (2012) Dietary vanadium induces decrease in antioxidant enzyme activities and oxidative stress in the spleens of broilers. Med Chem DOI: 10.4172/2161-0444.1000110.

23. Thompson CB (1995) Apoptosis in the pathogenesis and treatment of disease. Science 267: 1456-1462.

24. Huang C, Zhang Z, Ding M, Li J, Ye J, et a1. (2000) Vanadate induces p53 transactivation through hydrogen peroxide and causes apoptosis. J Biol Chem 275: 32516-32522.

25. Lee JH, Jung JY, Jeong YJ, Park JH, Yang KH, et al. (2008) Involvement of both mitochondrial- and death receptor-dependent apoptotic pathways regulated by $\mathrm{Bcl}-2$ family in sodium fluoride-induced apoptosis of human gingival fibroblasts. Toxicol 243: 340-347.

26. Roset R, Ortet L, Gil-Gomez G (2007) Role of Bcl-2 family members on apoptosis: what we have learned from knock-out mice. Front Biosci 12: 4722 4730 .

27. Oltvai ZN, Milliman CL, Korsmeyer SJ (1993) Bcl-2 heterodimerizes in vivo with a conserved homolog, Bax, that accelerates programmed cell death. Cell 74: 609-619.

28. Rana SVS (2008) Metals and apoptosis: recent development. J Trace Elem Medi Biol 22: 262-284. 